\title{
Corrigendum
}

\section{Total, insoluble and soluble dietary fibre intake in relation to blood pressure: the INTERMAP Study - CORRIGENDUM}

Ghadeer S. Aljuraiban, Linda M. O. Griep, Queenie Chan, Martha L. Daviglus, Jeremiah Stamler, Linda Van Horn, Paul Elliott and Gary S. Frost

(First published online 21 September 2015)

doi:10.1017/S0007114515003098, Published by Cambridge University Press, September 2015

Key words: Dietary fibre: Insoluble fibre: Soluble fibre: Blood pressure

The second author of this paper was incorrectly identified as Linda M.O. Griep. The correct name should be Linda M. Oude Griep.

\section{Reference}

Aljuraiban GS, Griep LMO, Chan Q, Daviglus ML, Stamler J, Van Horn L, Elliott P \& Frost GS. Total, insoluble and soluble dietary fibre intake in relation to blood pressure: the INTERMAP Study. British Journal of Nutrition, available on CJO2015. doi:10.1017/ S0007114515003098. 